\title{
Kitchen, the Forgotten Land of Microbiology: Who Look shall Find
}

\author{
Jose Iñaki Alava Marquinez* \\ Basque Culinary Center, Mondragon University, Spain
}

Submission: May 10, 2018; Published: June 27, 2018

*Corresponding author: Jose Iñaki Alava Marquinez, Basque Culinary Center, Mondragon University, Paseo Juan AbelinoBarriola 101, San Sebastian-20009, Spain, Tel: +34678622531/+34902540866; Email: ialava@bculinary.com

Abstract

Kitchen and culinary arts are origin of microbiology and biotechnology. Fermentations, microorganism's culture, pasteurization, sterilization and many other scientific processes, have their origin, in culinary processes that are more or less handmade. Now, when biotechnology and microbiology are part of our daily lives, we have put aside microbiology in the kitchen. Industrial food and fast food are pretty safe, but no questions, when a popular chef on TV, mixes a salad with dirty hands. Perhaps it is time to look again at the kitchen and culinary procedures. Modern hygienic procedures ensure the safety of food, in the kitchen of homes and restaurants. We have stopped looking where we should. European agencies, in charge of epidemiological and food surveillance, EFSA (European Food Safety Authority) and ECDC (European Centre for Disease Prevention and Control), have raised the alarm about the increase in diseases caused by micro-organisms typical of foods, such as Salmonella, Listeria and E Coli. If we look among our kitchen utensils, surely we will find unexpected microorganisms and new knowledge. This mini-review shows how in recent years a few researchers have turned their eyes to the kitchen and found surprising and disturbing results.

Keywords: Kitchen; Culinary; Hygiene; Safety; Cross-contamination; Sanitation

\section{Introduction}

The incidence of food-borne diseases in Spain, as it happens in most European countries, has increased significantly in recent years [1]. Outbreaks number of infection and intoxication that have occurred continues to be considered to be much higher than those officially recorded. There is a growing percentage of the population exposed to risky situations. Those who eat regularly outside their home, frequently eat ready to eat meals and homemade culinary fans.

The importance of contaminated surfaces in spreading pathogenic microorganisms to foods is already well studied and prevented in food processing, catering and domestic environment $[2,3]$. But many times we forgot to look in some unusual surfaces like, menus [4], food handlers [5], dishcloths [6], cutting board [7-9] or simply kitchen steel surfaces [10]. Is a fact, that EFSA is trying to ensuring European food safety [11] and ECDC is disquiet due to spreading of salmonellosis [12] and others food related microorganism [1] in the recent years.

\section{Discussion}

The main question is: why? In our opinion they are three different reasons. First of all, is acquired resistance of food microorganism like Salmonella to antibiotics and logical spreading of these strains to food chain [13]. In addition, many of these microorganism, have cross-resistance to biocides and antimicrobial agents like: Escherichia coli [14], Staphylococus aureus [15], Listeria monocytogenes [16] and of course Salmonella [17]. It must be borne in mind, that some of these microorganisms are bio film-forming [18], that protect other underlying species and one of the most dangerous are hemorrhagic strains of Escherichia coli [19]. Second reason, is effectiveness of hygiene procedures in kitchens during food cooking. Contaminated hands, cutting boards, knives and a low educational level are the perfect vectors of pathogen microorganism [20]. Defective hygiene procedures [21] are in origin of spreading of Salmonella [22,23], Campylobacter [24,25], Staphylococus aureus [26] and many other species, associated to kitchen surfaces [27].

Lack of knowledge, in hygiene procedures result in important increase food-borne infections from in-home culinary preparations, including those of kids and infants [28]. The last reason is that surely our hygiene procedures are not adequate. Detergent and bleach-based disinfection procedures are day by day less effectives [29]. Dish-washing does not sufficient to prevent cross- contamination and open a way to create new bio films on kitchen surfaces [30]. Even bleach-based or enzymatic cleaner aren't enough to assure a full disinfection of home surfaces [31,32]. 
Interspecies intercommunications help formation of easily to spray bio films [33], Seasonal occurrence of outbreak due to bio films in kitchen surfaces, every time related with Escherichia coli or Staphylococus aureus, Salmonella [4,34,35], it made us suppose that the propagation vector could be the cloths themselves. High content of organic materials in cloths will protect microorganism from biocidal action of detergents and bleach $[36,37]$. These cross-contaminated cloths are perfects to shoot bio films over kitchen surfaces [38].

\section{Conclusion}

If we do not look with a critical eye towards the kitchen and the culinary, forgetting where we come from, there is a risk that the food toxins continue their extension and the problem becomes uncontrollable. The cross resistance to the biocides, the poorly trained professionals or fans to the homemade kitchen, and finally the presence of bacterial load in the cloths, are problems that the scientists cannot leave aside, only because they happen in our kitchen. Its time see what is behind the menu.

\section{Acknowledgement}

We would like to thank the Basque Culinary Center for providing us with installations and budget to achieve this challenging goal. Thanks to my colleges Nerea Laburu, Miguel Angel Lopez and Catherine Montes for their comments.

\section{References}

1. European Commission (2015) The European Union summary report on trends and sources of zoonoses, zoonotic agents and food-borne outbreaks in 2014. EFSA Journal 13(12): 4329.

2. Elizabeth M, Stephen F, Lindsay, Fletcher, Susanne (2015) Cleaning and sanitation of salmonella-contaminated peanut butter processing equipment. Food microbiology 46: 100-106.

3. Alan L, Robert P (1993) Dinner date with a microbe. The American Biology Teacher 55(5): 268-274.

4. Martin, Mengual M, Carcedo I, Lopez MA (2016) Pathogen persistence in restaurant menus: comparison between materials. J Food Microbiol Saf Hyg 1(1): 1-5.

5. Mengual M, Martin, Carcedo I, Lopez MA, Alava JI (2016) Accessorizes of food handlers and restaurant staff as a source of food contamination. J Food Microbiol Saf Hyg 1(1): 5-10.

6. Ellen W, Louise M, Adrian C, Peters, Elizabeth (2014) Society for applied microbiology. PECS, UK.

7. Zhao P, Zhao T, Doyle MP, Rubino, Meng J (1998) Development of a model for evaluation of microbial cross-contamination in the kitchen. Journal of Food Protection 61(8): 960-963.

8. Nese O, Dean O, Charles W (1994) Cutting boards of plastic and wood contaminated experimentally with bacteria. Journal of Food Protection 57(1): 16-22.

9. Møretrø T, Pettersen GS, Olivier H, Ever H, Solveig L (2011) Assessment of the antibacterial activity of a triclosan-containing cutting board. Int J Food Microbial 146(2): 157-162.

10. Lelièvre, Patrick L, Cécile G, Jack L, Christine F (2002) Cleaning in place: effect of local wall shear stress variation on bacterial removal from stainless steel equipment. Chemical Engineering Science 57(8): 1287-1297.

11. European Food Safety Authority (2016) Science protecting consumers from field to fork. Corporate Brochure, UK, pp. 1-12.

12. European Centre for Disease Prevention and Control (2018) Salmonellosis. Annual epidemiological report for 2015, Stockholm, Sweden.

13. David G, White, Zhao, Robert, Sherry, et al. (2001) The isolation of antibiotic-resistant salmonella from retail ground meats. The New England Journal of Medicine 345(16): 1147-1154.

14. Braoudaki M, Hilton AC (2004) Adaptive resistance to biocides in salmonella entérica and escherichia coli 0157 and cross-resistance to antimicrobial agents. Journal of Clinical Microbiology 42(1): 73-78.

15. Suller MT, Russell AD (2000) Triclosan and antibiotic resistance in staphylococus aureus. J Antimicrob Chemother 46(1): 11-18.

16. Holah JT, Taylor JH, Dawson DJ, Hall KE (2002) Biocide use in the food industry and the disinfectant resistance of persistent strains of Listeria mono cytogenes and escherichia Coli. J Appl Microbiol Symposium Supplement 92: 111S-120S.

17. Condell O, Iversen C, Cooney S, Power KA, Walsh C, et al. (2012) Efficacy of biocides used in the modern food industry to control salmonellalinks between biocide tolerance and resistance to clinical relevant antimicrobial compounds. Appl Environ Microbiol 78(9): 3087-3097.

18. Mah TF, O’Toole GA (2001) Mechanisms of bio film resistance to antimicrobial agents. Trends in Microbiology 9(1): 34-39.

19. Braoudaki M, Hilton AC (2004) Low level of cross-resistance between tricosal and antibiotics in escherichia coli K-12 and E. coli 055 compared to E coli 0157. FEMS Microbiol Lett 235(2): 305-309.

20. Kennedy J (2011) Determinants of cross-contamination during home food preparation. British Food Journal 113(2): 280-297.

21. Cogan T, Bloomfield SF, Humphrey TJ (1999) The effectiveness of hygiene procedures from chicken carcases in the domestic kitchen. Lett Appl Microbiol 29(5): 354-358.

22. Parry SM, Slader J, Humphrey T, Holmes B, Guildea Z, et al. (2005) A case-control study of domestic kitchen microbiology and sporadic salmonella infection. Epidemiol Infect 133(5): 829-835.

23. Mendoça S, Juliano G, Cibeli V, Thiago I, Luciano, et al. (2012) Transfer of salmonella enteriditis to four types of surfaces after cleaning procedures and cross-contamination to tomatoes. Food Microbiol 30(2): 453-456.

24. Humphrey TJ, Martin KW, Slader J, Durham K (2001) Campylobacter spp. in the kitchen: spread and persistence. Journal of Applied Microbiology 90(S6): 1-10.

25. Usha MR, Tunung, Chai, Ghazail, Cheah, et al. (2010) A study on campylobacter jejuni cross-contamination during chilled broiler preparation. International Food Research Journal 17: 107-115.

26. Maria, Maria R, Liana J, André K, Fabiana C, et al. (2008) Comparison of Staphylococus aureus isolates from food handlers, raw bovine milk and Minas Frescal cheese by antibiogram and pulse-field gel electrophoresis following Sma I digestion. Food Control 19(2): 200207.

27. Gilberto E, Flores, Caporaso JG, Lauber CL, Leff JW, et al. (2013) Diversity, distribution and sources of bacteria in residential kitchens. Environ Microbiol 15(2): 588-596.

28. Elizabeth C, Redmond, Christopher J, Griffith (2009) The importance of hygiene in the domestic kitchen: Implications for preparation and 
storage of food and infant formula. Perspectives in Public Health 129(2): 69-76.

29. Barker J, Naeeni M, Bloomfield SF (2003) The effects of cleaning and disinfection in reducing salmonella contamination in a laboratory model kitchen. J Appl Microbiol 95(6): 1351-1360.

30. Jong L, Verhoeff B, Nauta M, De Jonge (2008) Cross-contamination in the kitchen: effect of hygiene measures. J Appl Microbiol 105(2): 615624.

31. Rusin P, Orosz C, Gerba C (1998) Reduction of faecal coliform, coliform and heterotrophic plate count bacteria in the household kitchen and bathroom by disinfection with hypochlorite cleaners. J Applied Microbiology 85(5): 819-828.

32. Mona A, Terhi A, FaikAtrosi (2004) Assessment of enzymatic cleaning agents and disinfectants against bacterial bio films. J Pharm Pharm Sciences 7(1): 55-64.

33. Rod MC, Richard J (2003) Microbial dinner-party conversations: the role of LuxS in interspecies communication. J Med Microbiol 52(7): 541-545.

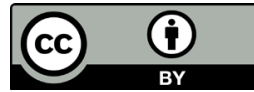

This work is licensed under Creative Commons Attribution 4.0 Licens DOI: 10.19080/AIBM.2018.09.555772
34. Ciccio AD, Vergara AR, Festino D, Paludi E, Zanardi, et al. (2015) Bio film formation by staphylococus aureus on food contact surfaces: Relationship with temperature and cell surface hydrophobicity. Food Control 50: 930-936.

35. Cogan TA, Slader J, Bloomfield SF, Humphrey TJ (2002) Achieving hygiene in the domestic kitchen: the effectiveness of commonly used cleaning procedures. J Appl Microbiol 92(5): 885-892.

36. Da Silva, Barbosa I, Alves AJ, Pinto D, Siqueira J, et al. (2012) Influence of temperature and surface kind on bio film formation by staphylococcus aureus from food-contact surfaces and sensitivity to sanitizers. Food Control 25(2): 469-475

37. Vasseur N, Rigaud M, Hébraud J, Labadie C (2001) Combined effects of $\mathrm{NaCl}, \mathrm{NaOH}$, and biocides monolaurin and lauric acid] on inactivation of Listeria monocytogenes and pseudomonas spp. J Food Prot 64(9): 1442-1445.

38. Nerea L, Adrián S, Iñaki J, Miguel A (2018) Reducing of bleach disinfectant power under remains of food in contaminated dishcloths in professional kitchens. International Journal of Gastronomy and Food Science (In Press).

\section{Your next submission with Juniper Publishers will reach you the below assets}

- Quality Editorial service

- Swift Peer Review

- Reprints availability

- E-prints Service

- Manuscript Podcast for convenient understanding

- Global attainment for your research

- Manuscript accessibility in different formats

( Pdf, E-pub, Full Text, Audio)

- Unceasing customer service

Track the below URL for one-step submission https://juniperpublishers.com/online-submission.php 